\title{
Imaginarios sociales acerca del turismo en Roses, Cataluña
}

\author{
Jesús Ángel Enríquez Acosta* \\ María Elena Robles Baldenegro \\ Universidad de Sonora
}

\section{Resumen}

Se estudia cómo los habitantes de Roses, Cataluña, representan e imaginan el proceso de turistificación por el que ha transitado la ciudad en años recientes. Los testimonios expresan un continuo proceso de construcción del sentido de lugar afectado por la actividad turística y los problemas asociados a ciudades en rápido crecimiento. Se trata de una ciudad fronteriza donde son dominantes el turismo de sol y playa y el de segundas residencias. En los discursos de los turistas y residentes entrevistados se manifiesta la imagen que identifica a la ciudad en términos del deterioro de las relaciones sociales ocasionado por el proceso de turistificación, y que vincula al turismo con los cambios en las condiciones de vida de la comunidad y con el aumento de las diferencias sociales.

Palabras clave

Roses, cambio social, comunidad, imaginarios, turismo.

Recibido: 08/10/2013 · Aceptado: 08/11/2013

*Correo electrónico:jesusenriquez@sociales.uson.mx / maria.robles@eca.uson.mx 


\title{
Social imaginaries with respect to tourism in Roses, Catalonia
}

\author{
Jesús Ángel Enríquez Acosta* \\ María Elena Robles Baldenegro \\ Universidad de Sonora
}

\begin{abstract}
This work studies how residents of Roses, Catalonia, represent and imagine the touristification process that the city has undergone in recent years. Evidence shows a continuous process of making sense of place affected by tourism activity and the problems related to rapidly growing cities. It is about a border city where the sun and beach tourism and the second residence tourism are dominant. Within the discourse of tourist and residents that were interviewed, the image representing the city in terms of the social relations damage caused by the touristification process is present. Likewise, there is a representation that relates tourism to the changes of the community lifestyle and to the increase of social differences.
\end{abstract}

KEY WORDS

Roses, social changes, community, Imaginary, tourism. 


\section{Introducción}

El objetivo de este trabajo es conocer los imaginarios sociales del turismo en Roses, Cataluña. Se contrastan los imaginarios sociales de Roses a partir de tres aspectos: significados, causas y consecuencias del turismo, mismos que sobresalen en las percepciones que residentes y turistas tienen respecto de esa ciudad. En los sujetos se observan las representaciones del cambio y la transformación social que posibilita la actividad turística. Las imágenes de las ciudades son subjetivadas por las experiencias y prácticas individuales y colectivas, lo que da sentido a las expresiones de identidad o desarraigo con los lugares. Es interesante que lo que los sujetos perciben es representado o significado de acuerdo con el lugar que ocupan en el espacio social, lo cual provoca el reconocimiento de las diferencias y distinciones que conforman el entramado social y, por supuesto, la representación de los problemas sociales y urbanos creados por la turistificación.

La investigación fue realizada de 2009 a 2011. El trabajo de campo consistió principalmente en la observación y en 36 entrevistas semiestructuradas a residentes y turistas, cuyas imágenes y percepciones están contenidas en sus relatos. A partir de estos se realiza una interpretación cualitativa y se refieren los significados atribuidos al lugar turístico en cuanto a las características naturales del enclave, la historia y la identidad local, las cualidades de la gente y la ciudad; se consideran las causas del fenómeno turístico como un proceso de transición y cambio social, cultural y urbano de las localidades, y se piensa en las consecuencias de la actividad turística en el tejido social, urbano, natural y cultural.

En la primera parte se expondrán algunos elementos conceptuales en torno a los imaginarios. También se incluye un apartado para contextualizar la ciudad de Roses, su historia, ámbito urbano, dimensión social y económica, entre otros elementos. En la segunda parte se analizan los relatos de las entrevistas para conocer los imaginarios sociales de turistas y residentes sobre la base de las significaciones, causas y consecuencias atribuidas por ellos al turismo. 


\section{Lo imaginario: marco teórico}

Por imaginario se entiende:

el conjunto de creencias, imágenes y valoraciones que se definen en torno a una actividad, un espacio, un periodo o una persona (o sociedad) en un momento dado. La representación que el imaginario elabora de un proceso, es construida a partir de imágenes reales o poéticas (inmersas en el campo de la fantasía). Variable y distendido, el imaginario es una construcción social -al mismo tiempo individual y colectiva- en permanente remodelación [...] el imaginario ofrece una construcción cambiante, tejida en parte a partir de las interpretaciones fantasiosas que expresa el individuo sobre el tema imaginado [Hiernaux, 2002: 8].

De ese modo, el imaginario forma parte de una representación en imágenes, creencias y valoraciones de determinadas actividades o espacios. Para el caso que nos ocupa, el imaginario del turismo se refiere a las representaciones que hacemos de la actividad turística en espacios, imágenes o discursos.

En la construcción de imaginarios se relacionan dos dimensiones: la objetiva y la subjetiva. Al respecto, es necesario precisar lo siguiente:

[la dimensión objetiva] son elementos que se desprenden de la estructura en que el actor establece sus prácticas vitales. Constituyen los elementos objetivos o condiciones materiales ya que son externos y no controlables por los individuos [...] Los subjetivos se construyen a partir de las aspiraciones, expectativas y valoraciones de este grupo humano [Goicoechea, 2003: 9].

El imaginario está constituido por elementos objetivos y subjetivos presentes en las prácticas sociales, donde es posible distinguir las diversas marcas, registros y procesos subjetivos individuales y colectivos. El imaginario y las prácticas sociales permiten establecer "los mecanismos de identidad y pertenencia urbana, pero además de la alteridad también se reproducen la diferenciación, la distinción y la segregación social. De esta manera la ciudad es cargada subjetivamente de significaciones, de sentimientos" (Nieto, 1998: 125).

En ese sentido, las ciudades turísticas no son solo un medio físico y material, sino también representaciones surgidas de las significaciones e interpretaciones que los individuos realizan, entre ellas la identificación con la ciudad, la experiencia de habitarla, los atributos y cualidades de la misma, las imágenes 
urbanas construidas, entre otras, que conforman el sentido de lugar. Al respecto, Fuentes dice que el sentido de lugar "no está dado por el propio lugar sino por las representaciones que le atribuyen los pobladores a los sitios, es decir, por las imágenes y los imaginarios que elaboran sobre lugares con atributos y significados particulares, que siempre son históricos y determinados por la cultura" (2000: 7).

Un componente del imaginario es la imagen. Los imaginarios de turistas y residentes se conforman de imágenes, creencias y valoraciones del lugar turístico construidas y representadas, que les permiten reconocer los procesos de cambio, valorar el lugar y sus cualidades reales o imaginadas, apreciar los problemas y las consecuencias no deseadas, así como distinguir la otredad y la exclusión. La imagen es símbolo y, como tal, se encuentra en proceso de resignificación permanente y en lucha por su apropiación. Lacarrieu piensa que las imágenes urbanas "son construcciones espaciales, culturales y sociales producto de campos de lucha simbólica. Son construcciones parciales, simplificadas y distorsionadas. Las imágenes no son la realidad, sino la representación de esa realidad" (2007: 51).

Al considerar las ciudades turísticas y sus imaginarios como procesos surgidos de las interpretaciones de individuos y grupos, conviene precisar qué entendemos por lugar turístico y cómo se liga con el imaginario social. Partimos del supuesto de que estos lugares están integrados al espacio de los flujos globales y que, en ese sentido, reproducen las tendencias urbanas contemporáneas que fragmentan el espacio y la diversidad social y reproducen la segregación social. De acuerdo con Borja y Castells (1998: 67), el espacio de los lugares "forma territorial de la cotidianidad y experiencia de la mayoría de la gente [...] está localmente fragmentado". La ciudad turística es tensada por los flujos globales y el sentido de pertenencia de la comunidad y el lugar como principio de identidad son alterados constantemente. Sin embargo, para este trabajo debemos entender el lugar turístico como representación construida por las experiencias de las personas, pleno de significados valorizados por la cercanía entre el sujeto y los espacios concretos; el lugar en su calidad de escenario de interacción diaria, con una especial carga simbólica y afectiva y como constructor de identidad social y territorial (Tuan, 1990). El lugar se liga al imaginario 
en cuanto representación de procesos subjetivos construidos por los individuos y por grupos sociales.

Los imaginarios sociales asociados al turismo "se construyen, (de)construyen y (re)construyen en el ámbito específico de la vida social que es el turismo concebido como espacio-tiempo opuesto al mundo de la vida cotidiana” (Fuentes, 2013: 157). Los imaginarios del turismo son elaboraciones de los turistas por medio de las cuales "perciben, dotan de sentido e intervienen como actores y espectadores en el fenómeno turístico”. El imaginario del turista incluye imágenes, fantasías, valoraciones, símbolos y significados acerca del lugar turístico. Estos componentes pueden ser valorizados como idearios turísticos o formas bajo las cuales los turistas se orientan respecto al lugar turístico, y expresan subjetivamente sus anhelos y deseos. Hiernaux (2002) identifica cuatro idearios dominantes que conforman los imaginarios del turista: la conquista de la felicidad, el deseo de evasión, el descubrimiento del otro y el regreso a la naturaleza. Tales idearios pueden observarse en las prácticas y experiencias realizadas por el turista para satisfacer sus deseos y fantasías. Para el turismo de segunda residencia, estos imaginarios tienen que ver con los idearios que lo alientan a seleccionar un espacio para vivir por temporadas o de manera definitiva; la imagen construida y apropiada por el turista se refiere tanto a elementos paisajísticos presentes en el medio natural y cultural como a los elementos simbólicos que dotan de sentido al lugar turístico.

Los imaginarios sociales de los residentes locales en cuanto al turismo se asocian con: a) valoraciones e imágenes construidas de la actividad turística, las posibilidades económicas ofrecidas por la actividad y el efecto transformador en la dinámica social, y $b$ ) imágenes decantadas en función de los cambios generados por este en la vida cotidiana. A diferencia del imaginario del turista -acorde a una realidad idílica, de fantasías y deseos-, el del residente local pasa de los mecanismos de creación de identidad y sentido de pertenencia al lugar a los procesos de diferenciación y reproducción social (Pereiro y De León, 2007), donde la actividad turística es valorada y representada de forma distinta que por el turista, es decir, con significados y sentimientos no necesariamente compartidos. 


\section{Breve reseña del lugar turístico de estudio}

Roses se ubica en la comunidad autónoma de Cataluña y pertenece a la provincia de Girona, en la comarca del Alto Ampurdán. Se localiza en el extremo noreste de Cataluña, colindando con Francia. La ciudad tiene un rico pasado histórico y cultural, existen vestigios arqueológicos de presencia griega, romana, visigoda y española. Con el transcurso del tiempo, y por su ubicación fronteriza con Francia, el puerto de Roses se constituyó en un estratégico punto militar, lo cual es observable en la llamada ciudadela, fortaleza militar que resguardó al asentamiento por varios siglos. También tuvo cierta importancia comercial en los siglos xvII y xviI por ser el puerto más cercano a Girona y Figueres, ciudades importantes de la región. No obstante, hasta bien entrado el siglo xx se mantuvo como un pequeño asentamiento de pescadores y agricultores dedicados al cultivo de vid y olivo, alrededor de la ciudadela destruida por los franceses a inicios del siglo xix. A mediados del siglo xx fue un pequeño pueblo flanqueado por la ciudadela y los pantanos, las montañas, los cultivos agrícolas y el mar, y atravesado por pequeños ríos que descendían de las montañas, con un incipiente turismo de las clases sociales más pudientes de las urbanizaciones vecinas.

Roses está rodeada por dos parques naturales protegidos: el Cap de Creus y el dels Aiguamolls. El primero es una cadena montañosa que nace en el mar Mediterráneo e inicia la cordillera de los Pirineos, que divide a España y Francia; el segundo es una zona de pantanos al pie de las montañas, que se extiende hasta la costa. La presencia de los parques naturales limita el posible crecimiento de la ciudad.

Las cosas comenzaron a modificarse para el pequeño asentamiento de pescadores y agricultores cuando se estableció una base militar estadounidense a finales de la década de los cincuenta. En el imaginario social de la comunidad la base militar significó una transformación significativa por la llegada de nuevos valores, utensilios modernos, gastronomía desconocida, entre otras cosas. A comienzos de la década de los sesenta los cambios se profundizaron con la construcción de los primeros hoteles y la llegada de turistas sobre todo franceses. Los turistas aprovechaban la diferencia de precios más bajos en España, la cercanía con la frontera francesa, el benigno clima de Roses y la belleza natural de la Costa Brava. 
A partir de la década de los sesenta se inicia la ocupación intensiva del litoral y el desarrollo del turismo masificado, a tono con el proceso de democratización del turismo, el baby boom posterior a la Segunda Guerra Mundial, las mejoras en los medios de transporte y la disminución de los costos de viaje. Roses comienza a transformar rápidamente su ámbito urbano y social pero también el paisaje natural. La zona de pantanos de los marismas (aiguamolls) es ocupada por canales para embarcaciones deportivas y el desarrollo de viviendas de segunda residencia, dando lugar al sitio llamado Santa Margarita. Comienzan a urbanizarse calas y pequeños puntos pesqueros entre los acantilados costeros, por ejemplo L’Almadrava y Canyelles. Las faldas de las montañas cercanas a Roses son invadidas por el turismo residencial, así pasó con el Puig Rom, pequeña montaña que domina la bahía de Roses. El turismo residencial rebasó el frente del litoral y subió a las montañas -los conjuntos urbanos de Mas Fumats y Mas Boscà-, donde se establecieron franceses y alemanes; y los antiguos campos de olivos se convirtieron en florecientes casas unifamiliares para turistas en Mas Oliva.

En la memoria colectiva de los habitantes permanecen ciertos hechos que marcaron a la comunidad: la crisis económica de los años treinta que afectó con gran severidad la actividad agrícola y pesquera, la guerra civil española, la llegada de los militares estadounidenses, la demolición de parte de las murallas de la ciudadela para construir viviendas turísticas, el arribo estacional de turismo del norte de Europa y la consiguiente modificación de estilos de vida locales, la transformación acelerada del litoral mediante hoteles y segundas residencias para turistas que ocupan gran parte del frente costero.

En la actualidad se piensa que el turismo masivo está en decadencia y declive como consecuencia económica de la entrada española a la Unión Europea y del aumento de precios por el uso del euro como moneda, pero no así el turismo residencial, a pesar de la crisis económica de años recientes.

Con todo, en el discurso de los gobiernos y empresarios se ofrecen otras modalidades de turismo con nuevos y viejos atractivos no considerados por aquel de sol y playa que caracterizó a Roses durante varias décadas, reconfigurando la imagen de marca de la Costa Brava con el ecoturismo, los abundantes parques naturales y el camping, el turismo cultural, la presencia de Salvador Dalí en la región, la recuperación del antiguo casco urbano, entre otros. 
Roses pasó de una población de 2703 habitantes en 1950 a 12991 en 2000, y para el año 2009 a 20197 habitantes, con una densidad de 440 hab. $/ \mathrm{km}^{2}$. La tasa de crecimiento es de tan solo $1.4 \%$, pero más alta que el promedio de Cataluña (1.15 \%) y España (1.08 \%). Los pobladores de Roses son sobre todo inmigrantes: $32 \%$ de ellos son de origen extranjero, tasa sensiblemente más alta que la de Cataluña (13.4 \%). Los inmigrantes de origen europeo (Francia, Alemania e Inglaterra) y que corresponden a población de segunda residencia constituyen $47 \%$; y $34 \%$ de la población extranjera es originaria del norte de África (en especial Marruecos y Argelia), en su mayoría trabajadores en el sector de servicios. Roses es un importante polo de atracción de inmigrantes en Cataluña, 57 \% de sus habitantes no nacieron en la ciudad. La población flotante de Roses llega a ser de hasta 70000 personas en la temporada alta del turismo -de junio a septiembre- (Barris, 2008).

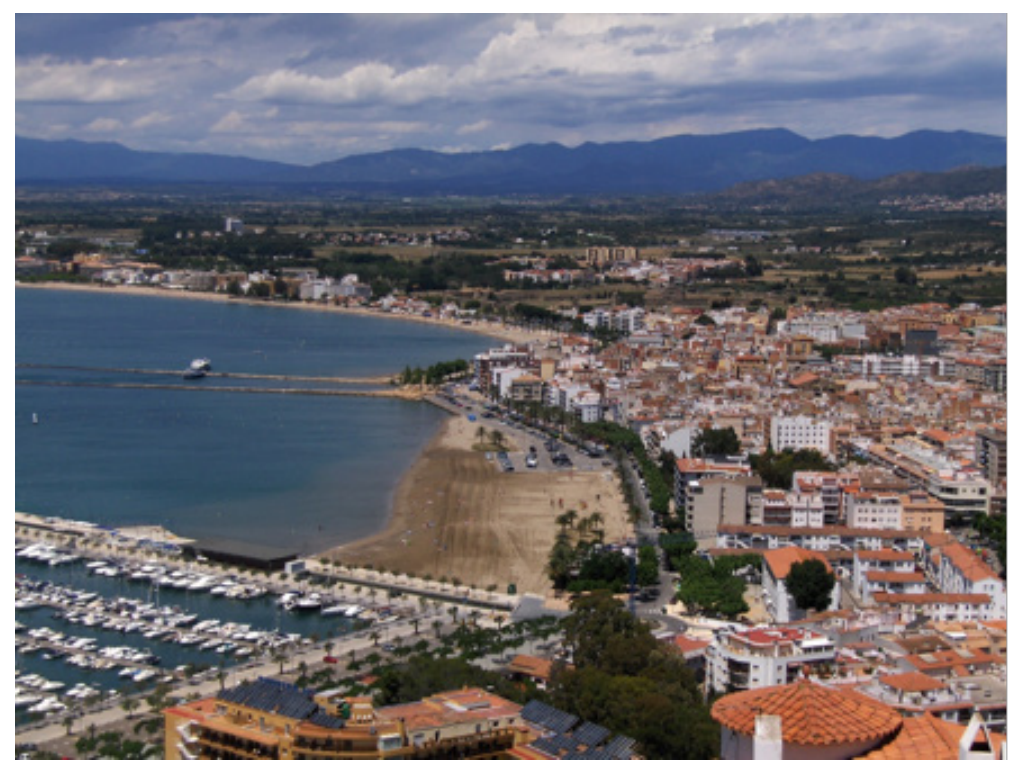

Figura 1. Vista de La bahía y EL CASCO históRico de Roses 
Existen 17000 viviendas de segunda residencia habitadas por turistas estacionales, a diferencia de las solo 4800 viviendas de los residentes que conforman el núcleo de la ciudad; la vocación esencial de Roses es la segunda residencia, estas viviendas alcanzan $80 \%$, a diferencia del alto Ampurdán, con $45 \%$ y Cataluña, con $15 \%$. La ciudad tiene 45 hoteles que suman 7000 cuartos. El sector de servicios, donde se ubica el ramo turístico, demanda dos terceras partes de la población ocupada y representa 70 \% de la economía local; sin embargo, es el sector que registra más despidos y más contrataciones por el carácter cíclico de la temporada turística de baja actividad en invierno y alta en verano (Municipio de Roses, 2007).

El modelo turístico implementado en Roses a partir de la década de los sesenta del siglo xx y hasta el presente implicó la ocupación masiva y acelerada de la costa por el proceso de turistificación, con el consiguiente progresivo cambio del paisaje costero y su sustitución por edificaciones hoteleras y de segunda residencia (Molleví y González, 2007). Hoy en día, Roses está limitada para crecer físicamente y también en cuanto a la actividad turística de alto impacto, dada la presencia de los parques naturales que la rodean, empero, la actividad turística se encargó, históricamente, de transformar el paisaje y el medio natural. Santa Margarita es el ejemplo más claro de cómo una actividad económica puede modificar de forma irremediable una zona de pantanos, así también la zona de montañas se vio alterada por las urbanizaciones de segunda residencia.

La ciudad se encuentra dividida y fragmentada funcionalmente. Por un lado, la zona del turismo, representada por Santa Margarita y los conjuntos de segunda residencia en el Puig Rom, Mas Fumats y Mas Boscà, los cuales ocupan, por temporadas, residentes extranjeros. Por otro lado, el antiguo asentamiento de pescadores que conforma el casco histórico y las urbanizaciones construidas recientemente para la población local. La ciudadela, al centro de la mancha urbana, separa ambos lados. Al igual que el paisaje ha sido afectado por los espacios turísticos, el tejido social se ha transformado por la población estacional, la inmigración europea y africana y el declive de las actividades productivas tradicionales como la pesca y la agricultura, procesos que por fuerza implican un cambio en la identidad y la memoria colectiva. 


\section{La buscada armonía: entrevistas a residentes y turistas}

Roses vivió una intensa y rápida ocupación del territorio costero. La ciudad pasó de una relativamente diversificada economía dedicada a la pesca y la agricultura a una masiva turistificación de sol y playa. En la actualidad, el modelo ha ido a menos y busca construir nuevas ofertas hacia grupos de población específicos: el ecoturismo y el turismo cultural. Pero en Roses el modelo ya transformó la ciudad y la sociedad de modo drástico, nuevos problemas aparecieron y otros renacieron. Para los habitantes, entre ellos los turistas de segunda residencia, es el momento de encauzar el desorden y restablecer la supuesta armonía perdida en años recientes. Este apartado trata los imaginarios y las percepciones de turistas y habitantes acerca del turismo, la ciudad, los problemas existentes y el futuro posible.

\section{Significados, causas y consecuencias del turismo}

LAS PERCEPCIONES DE LOS TURISTAS AVECINDADOS EN ROSES

Los turistas de segunda residencia asentados en Roses tienen una percepción positiva de las playas y del paisaje costero. El medio natural distingue al lugar y contribuyó en la decisión de radicar allí.

Las vistas son magníficas, hay vistas o calas que no están a veces al alcance de... si las conoces son una maravilla [turista francesa residente en Roses, 55 años].

La playa. Todos vienen por la playa, mi familia en verano, todos, mis amigos, mi familia viene por la playa, y eso a mí me encanta [turista francesa residente en Roses, 58 años].

El lugar es muy bueno, tiene playas fantásticas [turista francés residente en Roses, 45 años].

En el imaginario del turista también destacan otras razones que atrajeron a la primera oleada de turistas en la década de los sesenta del siglo xx: la cercanía de la frontera, las facilidades para la compra de vivienda de segunda residencia y los precios más baratos en España que en sus países de origen. 
Por estar cerca de la frontera, por el sol. Con Francia hay una diferencia muy grande de temperatura. Los precios al principio eran muy atractivos para los extranjeros. Al principio no conocía a nadie, venia de vacaciones y ya [turista francesa residente en Roses, 58 años].

Es una mezcla de todo, vecindad con Europa, los precios, los turistas [...] entonces pues era muy fácil acceder a Roses. Era muy fácil tener, comprar un chalet, una segunda residencia, el precio. Venían aquí y como aquel que dice, ahorraban con el cambio, con el cambio del franco, especialmente hubo mucho turismo francés, pues muy bien, muy bien y mucha jubilación. Entonces pues franceses se han ubicado en estos edificios o viviendas de segunda residencia que hay en Roses [turista francés residente en Roses, 64 años].

Roses aparece en el imaginario inicial de los turistas como un pequeño lugar dedicado a la pesca, en proceso de paulatina transformación bajo la influencia del turismo:

Era entonces un pueblo pesquero, ni un puerto. Había puerto pero no de la importancia que fue adquiriendo luego con el tiempo, y era un pueblo sencillo, pueblo de pescadores, vivían prácticamente de la pesca y de la agricultura, con poca comunicación respecto de las ciudades o los pueblos de alrededor y hacia al 53 o 55 aproximadamente, empezó pues el turismo paulatinamente, se introdujo y un boom alrededor de los setenta [turista polaca residente en Roses, 55 años].

Cuando trabajaba todavía estaba en Francia, hace tres años que estoy aquí, porque cuando trabajaba venía tres o cuatro meses al año y mira, se veía Roses engordando, no sé cómo decirlo, y como no tenía relaciones con los del pueblo, en esta época, no me dio, no me di cuenta al principio, no había asfalto en las calles, ni nada, era un pueblecito muy pequeño. Pobre. Había muy pocos coches y todos estropeados, muy feos y ahora es una ciudad normal, ieh? [turista francés residente en Roses, 62 años].

Las características naturales del lugar contribuyeron a construir la imagen de Roses como una ciudad marcada por dos ciclos: veranos bulliciosos e inviernos tranquilos. Incluso para los turistas de segunda residencia el periodo veraniego es insoportable. 
No, no, en verano no funciona, para nosotros es malísimo. Mucha gente en verano se marcha de Roses, se van de vacaciones, mucha gente en Mas Fumats también se marcha en verano, alquilan la casa y se van de vacaciones [turista francés residente en Roses, 58 años].

El ambiente de Roses [...] tienes que diferenciar la época del año. Es decir, en la época de verano prácticamente, es un ambiente en donde [...] hay dos grupos principales. Un primer grupo que está trabajando las 24 horas o más y el otro grupo que está viviendo del otro [...] que es el que viene de fuera. Eso en la época de verano, y en la época de invierno como no viene turismo teóricamente, pues entonces tienes a los de toda la vida, pues que se quedan aquí [turista francés residente en Roses, 62 años].

El turismo de sol y playa que caracteriza a Roses permitió la masificación de la actividad, la ciudad creció y también sus problemas. En el imaginario de los turistas radicados en la ciudad destaca la imagen de la ciudad como un lugar problemático por la vida cada vez más compleja y urbanizada.

Me gustaba más antes cuando era un pueblecito que ahora [que] hemos pasado los 20000 habitantes y somos una ciudad. Después hay cosas que cambian y cara al coche muy difícil, cara a [...] ahora hasta en invierno es más difícil que antes, antes se podía aparcar el coche donde querías ir, querías ir al ayuntamiento, podías aparcar delante del ayuntamiento. Ahora es muy difícil [turista francesa residente en Roses, 58 años].

Los extranjeros radicados en la ciudad como turistas de segunda residencia tienen una imagen negativa de la ciudad, de los servicios suministrados y del turismo. El desencanto aflora en sus percepciones.

Roses es bonita de cara al mar es una cara delante y una cara detrás. Para mí Roses es solo aquí delante. La Roses de los turistas es todo esto, lo demás [...] El ayuntamiento, el puerto y Santa Margarita y todo el paseo hasta Santa Margarita. La cara de atrás de Roses, desagradable. Santa Margarita en invierno desagradable, muy desagradable, está vacía, es sucia [presidenta comunidad francófona, 57 años].

Ha habido una superexplotación del espacio y se ha edificado para mí sin control durante muchos años, entonces para mí no es una ciudad ideal en cuanto a la po- 
blación, y yo no la considero una población bonita. No hay un casco antiguo [...] conservado, de hecho del casco lo que era es externo a lo que es la población y entonces no hay un casco como en muchas poblaciones, antiguo, conservado que pueda ser de atractivo turístico. Ha costado muchísimo durante muchos años [...] Y yo creo que esto es en detrimento del turismo que puede buscar [...] una ciudad de cualidad [presidente comunidad extranjera en Mas Fumats, 62 años].

Lo que pasa es que a Roses le falta una cosa porque Roses, para nosotros que venimos de Europa, falta un Corte Inglés, falta un comercio grande, un gran almacén, un centro comercial. Seguimos siendo de pueblo, tienes que irte a Girona. Ahora ya me he acostumbrado pero cuando llegué, los primeros años es muy duro, porque yo salía de casa en Alemania, me iba al centro con las amigas, de compras, compraba el botón, compraba las chuletas [turista alemana residente en Roses, 62 años].

Roses es caro, pero como calidad de tiendas es muy pobre, son todas tiendas de turistas y de souvenirs. No tenemos nada de [...] si buscas algún tipo de marca, nada, te vas a la playa que están los negros que venden. Roses para mi opinión tiene un turismo muy pobre [turista francés residente en Roses, 45 años].

Los turistas avecindados en Roses se consideran parte de la ciudad, sus estancias son largas, no se conciben como turistas de ocasión y poco involucrados en los asuntos públicos, por lo que sienten como suyos los problemas de la ciudad. Además, demandan atención de las autoridades de la ciudad.

Falta un buen servicio de autobús, transporte público que no está y faltan desplazamientos, que es una gran mala cosa de Roses. Es todo en catalán, el problema es que Roses tiene muchos extranjeros y no hacen nada para ellos, ni tenemos espectáculos ni tenemos nada. Han hecho ahora el curso de historia de Cataluña en catalán, en catalán para los extranjeros. Yo puedo ir porque comprendo. No lo hablo pero lo leo y no hay problema, yo puedo ir, pero están haciendo cursos del ayuntamiento que no sirven para nadie [turista francés residente en Roses, 64 años].

Son muchos los rincones desagradables porque el ayuntamiento no limpia. Tenemos recogida de basura, tenemos recogida de restos forestales, sí, pero las calles que yo vivo allí nunca la han limpiado. Eso es un punto que vamos a [...] Y tenemos las rieras, las canalizaciones de las casas bajan por las rieras que son secas, los desagües o 
incluso el agua también sube por alguna de las partes, entonces son canalizaciones antiguas con 30 o 40 años y en algunos lugares necesita reparación. El teléfono va fatal allí, si hay tormenta... [presidenta comunidad francófona, 57 años].

Como habitantes de Roses, los turistas de segunda residencia tienen conocimiento de los problemas de la ciudad y de las limitaciones del turismo; ellos mismos son ciudadanos preocupados por el futuro. La información que reciben les permite construir una imagen del futuro de Roses a partir de observar la realidad del presente.

Roses no puede crecer más en cuanto a edificación, está sobreedificado; Roses, puede tener pequeños retoques pero es de muy mal arreglo porque está superedificada y entonces pues lo único [factible] es mantener y no edificar más y mantener los espacios naturales en el máximo de lo posible, que no se deterioren más de lo que ya se han deteriorado [turista polaca residente en Roses, 55 años].

\section{Significados, causas y consecuencias del turismo}

LAS PERCEPCIONES DE LOS HABITANTES DE ROSES

Los habitantes de Roses tienen una percepción muy diversa de su ciudad. Esta creció mediante la inmigración en los últimos 40 años y el turismo facilitó los flujos de nuevos residentes, lo cual le da un aire muy particular al tejido social de la ciudad pero también a la forma de valorarla y sentirla. Las visiones son múltiples y contradictorias dependiendo del origen del entrevistado. Sin embargo, las imágenes que identifican al lugar y que están en la memoria colectiva se expresan en el valorado patrimonio histórico y cultural: la pesca, el medio natural, los paisajes y la costa. Los habitantes asocian su ciudad al mar, la costa, los viñedos y olivares, la ciudadela y su pasado.

A ver, el clima está bien, y sobre todo en verano el tema que te decía de la playa, la zona virgen, las costas, las calas estas que hay pequeñitas, esto está, está muy bien. O sea quieres una cosa que hay que ir a ver, pues el tema de la Costa Brava norte, pues está realmente bien [comerciante, 50 años].

Fuera de Roses, por ejemplo, la vista desde los altos del Puig Rom y todas las vistas que hay yendo por la montaña. Por toda la zona interior de montaña hay unas vistas espectaculares, unas calas fantásticas, es muy espectacular, realmente es muy 
espectacular, sí. Y de dentro, bueno a mí hay una zona que me gusta mucho y es el ensanche, son unas tres o cuatro calles y una plaza, la plaza Prim, del general Prim, que es un ensanche de finales del xix y tiene un carácter muy colonial por la tarde en verano. Pero también es mágica la ciudadela; pasearse por la ciudadela, la línea de costa, el paseo, es agradable. Es agradable pasearse por la parte antigua, las callejuelas, sobre todo cuando no hay turistas, está todo más cerrado, es más introspectiva, tiene gracia, tiene gracia [jubilada, 66 años].

Dentro de la ciudad, la ciudadela, que es la fortificación. Y fuera de la ciudad cuando entras en el Cab de Creus, la roca negra que corta y que baja hasta el agua es brutal, visto desde el mar y visto desde arriba [profesor, 55 años].

La imagen de Roses que persiste en el imaginario social plantea una realidad muy dura y difícil antes de la llegada del turismo, ligada a las dificultades de la vida cotidiana, a las actividades tradicionales como la pesca y el cultivo de la vid y el olivo; el turismo era complementario y se reducía a la renta de habitaciones o casas, lo que ayudaba a la economía familiar en los momentos de apuro. Es la historia de una comunidad frente al mar, lejana a la región, al país y a la modernidad.

Aquí se vivía de la agricultura y la pesca, no hay más. O sea de aquí, para que se hagan una idea, mi abuelo en concreto, mi abuelo materno, iba por las mañanas al olivar o a la viña y por las noches se iba a cerco a pescar para pagarse la seguridad social. O sea que ya se habrán hecho una idea de lo que era el pueblo [pescador, 60 años].

Bueno pues ha habido un cambio muy grande, porque antes la gente de la mar no vivía solo del mar, vivía también de lo que cultivaban en un pequeño huerto y cuando vino el turismo pues incluso [...] se alquilaban habitaciones en las casas. Alquilaban habitaciones para poder subsistir porque claro [...] eran tiempos [en] que no había mucha cosa [...] para comer. La tienda normalmente [...] ibas ahí apuntando y luego se iba pagando. Tenías un poco de la pesca, un poco del huerto y luego con el turismo. Primero llegaron también los americanos a Paní, a la base de Paní, y esto empezó ya a dar vida al pueblo de Roses. Luego con el turismo ha habido una transformación [...] ha sido enorme, en todos los sentidos [alcaldesa de Roses, 56 años]. 
De ese modo, en el imaginario social permanece la imagen de una realidad dura, el "antes" desde el cual se valoran las cosas y se reconoce el presente, es decir, se construye un sentido de lugar y la dimensión temporal del imaginario. Asimismo, la historia del lugar -representada materialmente en restos arqueológicos y en lo que queda del casco viejo de la ciudad- alimenta la dimensión espacial del imaginario. Hay quien representa a Roses como un parque temático:

Roses es un parque, un parque temático en miniatura. Sí y es difícil encontrar esto. A ver, me explico, tenemos por ejemplo, a nivel patrimonial, en cultura. Es un parque temático en miniatura, hay restos neolíticos, del cuaternario neolítico, de época íbera, griegos, romanos, alto medievales, bajo medievales, de época moderna, de época contemporánea y está todo aquí. Incluso más, está todo dentro de la ciudadela. En la ciudadela casi se encuentra todo, desde Grecia hasta la actualidad. Desde la primera casa que hizo un griego hasta la voladura de la muralla del levante de 1963, cuando ya era declarado monumento artístico nacional [...] Hay más, el hecho que te comentaba antes de tener dos parques naturales, nacionales. Muy pocas poblaciones pueden tener dos parques nacionales. El setenta y pico por ciento del territorio está protegido, esto la distingue [empleado de la alcaldía, 50 años].

Las cualidades naturales, la riqueza histórica de Roses y otras razones más son las imágenes que componen el imaginario turístico y permiten a la comunidad explicarse el boom turístico ocurrido a partir de los años sesenta del siglo xx.

[Esto se debe] a varios factores, el primero es el puramente físico, geográfico, la situación con Francia, la situación litoral y dentro de la situación litoral la situación local. O sea, Roses es un pueblo físicamente atractivo con unas grandes tardes, por ejemplo, es el único pueblo de costa, de la costa levantina que mira al poniente, que tiene unas buenas tardes, cuando los otros pueblos están ya a oscuras aquí todavía vemos las puestas de sol. Estos son los atractivos físicos inmediatos, pero básicamente es la situación con Francia y el carácter litoral no [hotelero, 68 años].

La Costa Brava como representación turística de marca para Cataluña está presente en el imaginario social de Roses, al igual que los lugares donde el pintor Salvador Dalí tuvo algunos pasajes de su vida. La ubicación de Roses dentro 
de un corredor cultural e histórico, el mar y la costa forman los atractivos para el turismo de segunda residencia y las imágenes de competitividad y posicionamiento frente a otros lugares.

Aparte de la zona del Crasch (paseo marítimo) que Roses puede contar como un centro donde la gente se mueve, a cuatro pasos está Figueres; quienes no quieran pues el museo Dalí tiene su atractivo; Cadaqués está relativamente cerca, con lo cual también la casa de Dalí, quizá ha sido un poco un atrayente, ¿no? Luego, lo que decíamos, toda la zona de Santa Margarita, mucha inversión alemana, bueno pues ha sido mucho segunda residencia para además de esto [empleada de turismo, 45 años].

También hay voces que discrepan de la representación de Roses como un lugar histórico, que critican la tematización de la ciudad con fines turísticos. Por el contrario, lo consideran un pueblo de pescadores sin mucho atractivo o pasado significativo.

Esta primera zona no es bonita, o sea, Roses no tiene un casco viejo. Vas a cualquier pueblo, y tiene algo, Roses no lo tiene, no tiene un casco viejo. Por todo esto que hemos hablado antes, porque ha sido de siempre un pueblo de pescadores y porque no tiene la tradición, no tiene nada, no hay casas buenas de estas que si te ponen, la casa de fulano, la casa de mengano, esas casas solariegas, esas casas antiguas, estas casas de la familia de siempre, no hay, yo no conozco ninguna. Que no ha habido nunca, nunca existieron, es un pueblo de pesca. Pues que eran barracas. Eran barracas completamente. Dése cuenta que aquí, en las zonas estas siempre ha habido invasiones, más o menos pacíficas, la gente no vivía en la costa, vivía en el interior, y entonces en la costa lo que había eran las barracas de los pescadores [profesor, 45 años].

La turistificación transformó la vida de Roses. La comunidad aprecia los cambios positivos ocasionados por el turismo porque permitieron el acercamiento con otras culturas, aparecieron nuevos estilos de vida y gustos, facilitaron la vida cotidiana y mejoraron la interacción con el turista extranjero. Todo en una sociedad relativamente cerrada, primero por el control de la dictadura española y después por la lejanía y el aislamiento geográfico. Hubo un deslumbramiento con lo nuevo y con las posibilidades ofrecidas. 
Aportan muchas cosas los turistas [...] Sus maneras de vestir, de expresarse, de moverse, de perderse. Aportaron más seguramente en el año 1965, cuando Roses era un pueblo plenamente franquista como país, que no habían visto nada, no conocían nada, estaban inmersos en un proceso represivo, todo estaba controlado. La llegada de turistas suecos o noruegos o ingleses o islandeses o franceses, pues hizo que la gente pues conociera otro mundo. Otro mundo. Este año, hace 50 años de la base, de la estación aérea de Paní. Fue hecha por americanos. La gente del pueblo flipaba ${ }^{1}$ con los americanos, flipaba. El aluminio, una cocina de aluminio. Lo mismo si aluminio, acero inoxidable, los coches, las lavadoras, los transistores, no habían visto nunca, y lo mismo aportaron, hablando del caso concreto de los americanos y lo mismo los turistas ¿no? Las minifaldas, las pantorrillas. Ver una chica medio desnuda no, con bikini, ¡haaaa!, dios mío. La gente te lo comenta, la gente lo comenta. Los platos combinados, una tontería, cómo un plato combinado. Cuatro papas fritas, un huevo duro, no sé qué, una hamburguesa, todo junto. La gente flipaba con esto, cómo un plato combinado. Aportó esto, coches nuevos, la moda, las costumbres, las costumbres cambiaron [...] No tenías que esperar al matrimonio para perder la virginidad y la gente del pueblo la perdió así, con turistas, la perdió bastante pronto, luego se casaron con mujeres o con hombres del pueblo. Pero la virginidad se perdió en una noche de verano en la playa [empleado de la alcaldía, 50 años].

Pero la transición del asentamiento pesquero al turismo no estuvo exenta de problemas. Se percibe que las cosas se hicieron mal, se privilegió el interés económico de las inmobiliarias y capitales hoteleros sobre las necesidades de la población y la ciudad.

Los turistas, de hecho el crecimiento fue un poco la cosa especulativa de las inmobiliarias junto con el boom turístico, esto fue lo más importante, después el pueblo fue creciendo muy mal porque crecía en una época solo haciendo casas, chalets un poco con gran desorden y luego llegó un momento en que se tenía que convertir en ciudad [...] hace como 12 o 14 años que en realidad se empezó a poner las pilas el pueblo para convertirse en ciudad y a dotarse de las infraestructuras, se cubrió la riera que ahora es una rambla pero que antes era riera, se hizo un teatro, la biblioteca, se arregló la ciudadela [arquitecto, 53 años].

${ }^{1}$ Alucinaba [nota del editor]. 
Pero el proceso también tuvo su desencanto o efectos no deseados. Un impacto significativo se sufrió en la pesca, sector tradicional y base de la economía local durante muchos años.

Entonces claro, fue un boom muy importante, se sigue manteniendo parte del pueblo pesquero, pero claro, ya no tiene nada que ver Roses con lo que había sido 20 años atrás. Ha habido una masificación bestial [...] Sí, realmente se ha quedado pequeño Roses, gente del país, lógicamente cada vez hay menos que se dedique a la pesca. Hay, bueno, es una de las zonas que hay bastantes barcos que salen a pescar y pequeños pescadores, pero ya no es lo que era [pescador, 65 años].

El pueblo no me gusta, las playas del pueblo no me gustan, son bulliciosas, los alrededores perfectos, geniales. A eso me refería, a la zona turística del pueblo, demasiada gente destrozando el encanto de lo que sería un pueblo pesquero, un pueblo de costa [profesor, 45 años].

La decepción se relaciona con la forma como el turismo permitió la llegada estacional de grandes cantidades de personas, modificó presuntos emblemas culinarios y los ofreció como artículos de consumo masivo, equiparándolos, por ejemplo, con un bloqueador de sol.

El puerto, encuentro que es un sitio agradable para ir, el puerto pesquero, no el deportivo. Desagradable el centro cuando está a reventar de gente comiendo algo que se llama paella, pero no saben ni lo que es y oler a coco, jajaja [jubilado, 67 años].

La ciudad fue transformada en su fisonomía. Para algunos entrevistados la masificación del turismo construyó un sector de ciudad no muy atractivo como es Santa Margarita. Allí, el turismo residencial tiene su expresión más visible, es la cara negativa. Por eso perciben que el costo del turismo ha sido muy alto.

Bueno hay bastantes hoteles pero hay más tirando a apartamentos. Hay grandes monstruos, sobre todo en Santa Margarita, enormes continentes de muchos, muchos apartamentos, lo que es bueno, se paga el precio del turismo ¿no?, estas masificaciones que, pues si quieres, diría un poco trompa al saber cuál es esta urbanización, pues es un poco complicado porque todas son iguales ¿no? O sea, pero bueno, a mí personalmente no me gusta, parecen ciudades dormitorio en este caso [...] hay quien vive de esto, el turismo, los hoteles, las discotecas, pero a veces se paga un precio, es muy concentrado y pequeño [regidor, 55 años]. 
El turismo se representa en el imaginario de la comunidad por su carácter cíclico. Es decir, se siente y observa como un mal necesario con duración de varios meses al año, luego de los cuales viene la calma.

El ambiente en Roses es cambiante, es decir, en invierno tienes un ambiente de pueblo grande, ¿de acuerdo? En el que la vida tampoco ha cambiado tanto, la gente va al mercado, va a las tiendas del pueblo, etcétera, etcétera. Y a partir de la primavera pues se va convirtiendo en una especie de marabunta que te intenta superar, de la manera que puede, con todo el tema de los ruidos por la noche, está claro, el tema del tráfico, la gente por la calle, la playa [hotelero, 61 años].

Ahora es mucho más tranquila, es muy bulliciosa en verano, es mucho más tranquila en invierno. Es fría en invierno, por el viento incluso, por la constitución de sus calles, su trama urbana. Es mucho más cálida en verano. Sería un poco todo, ¿no?, es una... como todas las sociedades, seguramente es compleja, ¿no?, y con muchas caras y muchos matices y en el fondo tampoco es una población únicamente turística, es una población todavía pesquera. Es un pueblo todavía, es una ciudad en otros aspectos. Es muy maleable, es muy dúctil, es de piedra, seguramente es de espuma [...] En verano es una cosa, ahora ya estamos en la época que es otra cosa. Hoy, por ejemplo, con tramontana, la gente corre por la calle, la que te ayuda la conoces, no hay esa olimpiada del mal gusto de verano, donde todo el mundo hace... muchas cosas [hotelero, 55 años].

La imagen conocida y representada de Roses fue transformada por el turismo. El sentido de lugar de la población y la identidad urbana se modificaron sin remedio y sus habitantes perciben distorsión y desorden en la imagen de la ciudad.

Cuando salimos a dar un paseo así o voy a casa pues yo me quedo parada cuando veo Roses porque no la conozco [jubilada, 66 años].

¿Roses, como ciudad? Muy fea, así de claro. Pues que ha crecido muy desordenadamente, muy desordenadamente. Y lo triste es que ha tenido la posibilidad de todo lo contrario [arquitecto, 45 años].

A los cambios físicos de la ciudad se agregan los sociales. Los habitantes advierten que su ciudad tiene nuevos problemas que la tensan. Uno de ellos es 
la visión de Roses como una ciudad sin identidad, sin sentido de lugar y poco cohesionada, debido a la presencia de muchas nacionalidades y la celeridad de las transformaciones, entre ellas la inmigración.

Hay muchas sociedades. Y de estas sociedades hay pocas líneas verticales, transversales, que las burlan [...] Ese es el gran déficit histórico de Roses. La falta de sociedad civil, de cohesión social y eso se nota mucho [profesor, 45 años].

Entonces gente de Roses, que se pueda decir de Roses, como por ejemplo, en cualquier otra ciudad, que están los bisabuelos, los tatarabuelos. No conozco a nadie. En el mejor de los casos, es gente que, bueno, que son dos generaciones viviendo aquí, pero lo general es que es gente la que vive aquí que, diciéndolo de una manera así, un poquitín rápida, ha venido a dar el pelotazo, a vivir, a montar algo, a sacar dinero y punto. Pero le falta, y estoy yo que me he movido por muchos pueblos de la zona, le falta esa solera de la gente que es del pueblo, de la gente que sus padres son del pueblo, que el apellido es del pueblo y que entonces lo que intenta [...], tiene un respeto incluso con ese apellido, con esa tradición. No hay arraigo, en absoluto, no lo hay [empleado de la alcaldía, 50 años].

En los relatos llama la atención el tema de los inmigrantes provenientes del norte de África. El imaginario de la migración es una forma de representar la realidad y los inmigrantes forman parte de la imagen de exclusión social. Las narraciones los ubican como el otro al que se le teme por ser diferente, poseer costumbres y tradiciones ajenas y opuestas a los patrones locales.

Pero sí que desestructurada socialmente, hemos perdido en cohesión social por supuesto, la enorme inmigración que ha venido afecta a la cohesión porque [...] de hecho es un pueblo que ha integrado siempre todo el mundo, vin[ieron] también en un momento dado muchos gitanos y se han integrado, pero en cambio los nuevos [...] los marroquíes y los musulmanes se integran muy mal. Aquí cuando vino la época también de los andaluces y la gente y todo esto, pero es un sitio donde la gente se integra muy bien, ipero es que la nueva hornada!, primero es que son demasiados y es muy difícil porque construyen sus propios guetos, entonces tiene una difícil solución [...] es un problema que tenemos aquí. Y el futuro y sobre todo pensando que quieren dar el voto a los inmigrantes, esto puede ser terrible porque habrá por fuerza, porque [...] la gente que tiene raíces quiere más al pueblo que la gente que no tiene raíces [regidora, 50 años]. 
Ocurre una cosa, que antes había una inmigración, ¿vale?, por ejemplo, yo diría que desde 1950 o una cosa así, quizá antes, de personas andaluzas, valencianos, tal, todo esto. Después, en esos momentos, Roses debe [de] estar del orden de $30 \%$ de inmigración magrebí, subsahariana y tal, todo esto. Si antes no ha habido identidad, ¿cómo la vamos a pedir ahora?, ¿que es malo?, ni es malo, ni es bueno. Quizá bueno, porque la globalización va por ese camino. Ahora, identidad no tiene el pueblo, y creo que cada vez la tendrá menos [arquitecto, 45 años].

Además, la imagen de decadencia del antiguo casco histórico de la ciudad aumenta al ser habitado por inmigrantes.

Es el barrio de la decadencia. Es el barrio [de] donde seguramente [se] ha marchado más población autóctona y donde la parte más antigua, la que da a la zona litoral es donde se percibe más la decadencia del núcleo urbano. Hay casas viejas, abandonadas. Y la gente de toda la vida, entre comillas, es la que ha marchado, a residencias mejores o a zonas mejores. Y se ha producido el típico, el típico proceso de sustitución por población emigrante, pues básicamente norteafricana ¿no? [empleado de la alcaldía, 50 años].

La imagen actual de Roses, tensionada por la inmigración y la falta de cohesión social, no inhibe la idea de la ciudad imaginada en el futuro. El imaginario social incluye a los inmigrantes y el delicado equilibrio vigente entre turismo y ciudad.

Roses en el año 2095 con 78000 habitantes, un alcalde magrebí, 3000 habitantes más que Figueres [...] ya me la había imaginado con un sector liberal importante [...] habrá el tren de alta velocidad un día de estos, supongo, por tanto es un lugar en que se puede vivir bien [empresario náutico, 56 años].

Yo pienso que ahora está en un punto en que hay que vigilar mucho, en que hay que vigilar mucho cualquier proyecto que signifique crecimiento, porque ahora está en un punto de equilibro que yo creo que es bastante adecuado. El puerto y la vida de la ciudad no se comen al turismo y el turismo se come a la ciudad, pero se la come durante un mes y medio, dos meses, entonces eso es soportable. En el momento que intentes, por ejemplo, levantar primera línea de playa con edificios automáticamente yo creo que arruinas el futuro del pueblo [alcaldesa, 56 años]. 


\section{Conclusiones}

Roses registra una marcada transformación social y urbana debida al intenso proceso de turistificación de las últimas décadas. Al parecer, el turismo masivo basado en la oferta de sol y playa y de segunda residencia agotó sus posibilidades de crecimiento, de acuerdo con las personas entrevistadas durante la investigación, pero también por las condiciones naturales y geográficas del lugar. La búsqueda de otras ofertas turísticas procura recuperar el patrimonio cultural y la naturaleza como alternativas al carácter cíclico del turismo.

El imaginario social dominante desprendido de los relatos de turistas y residentes refiere que el lugar adquirió nuevas dinámicas sociales y urbanas muy distintas a su rica historia cultural. La tradicional ciudad dedicada a la pesca y agricultura se ve perdida frente a la acelerada transición de años recientes hacia la actividad turística como principal vocación económica. Las descripciones de los entrevistados apuntan al deterioro de las relaciones sociales ocasionado por el proceso de inmigración turística que ha significado el turismo residencial europeo y el empleo de migrantes del norte de África en los servicios. Asimismo se vincula el turismo a los cambios en las condiciones de vida de los habitantes, a las formas de hacer ciudad y al aumento de las diferencias sociales expresadas como exclusión social y creación de otredad representada en el inmigrante.

Los imaginarios sociales de los habitantes y de los turistas avecindados en Roses se caracterizan por los significados atribuidos a su ciudad en términos de sus atractivos naturales y culturales, que les permiten crear el sentido de lugar. Esos atractivos propiciaron el turismo masivo pero también contribuyeron a transformar la dinámica social y económica de una pequeña comunidad basada en las actividades primarias a otra a tono con los procesos globales del turismo.

En el imaginario social hay coincidencia en la celeridad de los cambios urbanos y sociales ocasionados por la actividad turística, aunque también en el carácter cíclico del turismo. Para los turistas, el imaginario de tranquilidad y diversión representado por Roses como atracción turística se modifica cuando se establecen relaciones afectivas con el lugar al asentarse por largas temporadas, interactuar con la población y comenzar a formar parte de una comunidad y de sus problemas. Para el residente, el imaginario del lugar guarda un gran significado por el sentido de pertenencia que conlleva, pero la actividad turística impregnó ese imaginario de nuevos valores e imágenes, trajo consigo diversos 
procesos sociales y económicos y efectos no vislumbrados en la vida cotidiana. Sin embargo, tanto en turistas como en residentes, el imaginario que permea es pensar su ciudad en términos de un relativo equilibrio entre el turismo, la dinámica social y urbana construida recientemente y los atractivos naturales y culturales.

\section{Fuentes consultadas}

Barris, J. (2008). Roses o la recerca de la zona grisa. Roses: Roses Publicacions Municipals.

Borja, J. y M. Castells (1998). Local y global. La gestión de las ciudades en la era de la información. Madrid: Taurus.

Fuentes, J. (2000). "Imágenes e imaginarios urbanos: su utilización en los estudios de las ciudades”. Ciudades, 46, 3-10.

------ (2013). “Los imaginarios del turismo contemporáneo, balance y perspectivas para la construcción del concepto”. Ensambles, 3.

Goicoechea, A. (2003). Los imaginarios migratorios, el caso ecuatoriano. Quito: Universidad Andina Simón Bolívar.

Hiernaux, D. (2002). “Turismo e imaginarios”, en D. Hiernaux, A. Cordero y L. Duynen, Imaginarios sociales y turismo sostenible. San José: Facultad Latinoamericana de Ciencias Sociales, 7-36.

Lacarrieu, M. (2007). “La 'insoportable levedad' de lo urbano”. Eure, XXXIII (99), 47-64.

Molleví, G. y L. González (2007). "Segundas residencias en la comarca del Alt Empordá”. Investigaciones Geográficas, 42, 125-143.

Municipio de Roses (2007). Informe Socioeconómico de Roses en 2007. Roses: Municipio de Roses.

Nieto, R. (1998). "Lo imaginario como articulador de los órdenes laboral y urbano". Alteridades, 8 (15), 121-129.

Pereiro, X. y C. de León (2007). “La construcción imaginaria del lugar turístico: Kuna Yala”. Tareas, 127, 61-96.

Tuan, Y. (1990). Topophilia: a Study of Environmental Perceptions, Attitudes and Values. Nueva York: Universidad de Columbia. 